\title{
Fungal and plant gene expression in arbuscular mycorrhizal symbiosis
}

\section{Raffaella Balestrini • Luisa Lanfranco}

Published online: 18 November 2006

(C) Springer-Verlag 2006

The online version of the original article can be found at: http://dx.doi. org/10.1007/s00572-006-0069-2.

R. Balestrini $(\square)$

Istituto per la Protezione delle Piante-Sezione di Torino-CNR,

Viale Mattioli 25,

10125 Turin, Italy

e-mail: r.balestrini@ipp.cnr.it

L. Lanfranco

Dipartimento di Biologia Vegetale, Università di Torino,

Viale Mattioli 25,

10125 Turin, Italy
Unfortunately, the publisher printed the legend of Table 1 with errors. The correct legend is given here:

Table 1 List of genes reported to be transcriptionally induced or regulated in a specific stage of AM symbiosis development. For untargeted approaches (EST, arrays, SSH) only the functional categories have been reported. Fungal genes are indicated in colour 